God's Peace and King's Peace 


\section{THE MIDDLE AGES SERIES}

Ruth Mazo Karras, General Editor

Edward Peters, Founding Editor

A complete list of books in the series is available from the publisher. 


\title{
God's Peace and King's Peace
}

\section{The Laws of Edward the Confessor}

\author{
Bruce R. O’Brien
}

\author{
$\overline{\text { PENN }}$ \\ University of Pennsylvania Press \\ Philadelphia
}


Copyright (C) 1999 University of Pennsylvania Press All rights reserved

IO 98765432 I

Published by University of Pennsylvania Press

Philadelphia, Pennsylvania 19104

Library of Congress Cataloging-in-Publication Data

O'Brien, Bruce R.

God's peace and king's peace : the laws of Edward the Confessor /

Bruce R. O'Brien.

p. cm. - (The Middle Ages series)

Includes bibliographical references and index.

ISBN o-8I22-346I-8 (cloth : alk. paper)

I. Leges Edwardi Confessoris. 2. Law-England-Sources. 3. LawEngland-History. 4. Law, Anglo-Saxon-Sources. I. Title.

II. Series.

KD544.O25 1999

$349.42-\mathrm{dc} 2 \mathrm{I}$

98-24540

CIP 


\section{To my parents}


This page intentionally left blank 